OCCASIONAL PAPERS

ON ISLANDS AND SMALL STATES

ISSN 1024-6282

Occasional Paper Number: 04/2018

\title{
Foreign exchange pressure in Barbados: monetary approach or monetary dependence?
}

\section{Darrin Downes \& Tarron Khemraj}

More information about the series of occasional paper can be obtained from the Islands and

Small States Institute, University of Malta. Tel: 356-21344879; email: islands@um.edu.mt. 


\title{
Foreign exchange pressure in Barbados: monetary approach or monetary dependence?
}

\author{
Darrin Downes, Central Bank of Barbados \\ Tarron Khemraj, New College of Florida
}

\begin{abstract}
This paper tests competing ideas accounting for the foreign exchange (FX) losses in Barbados in recent years. The conventional monetary and absorption approaches have motivated the explanation and policy proposals to date. However, this paper illustrates that the conventional theories fail to account for the external forces determining FX pressure. We propose a theory of monetary dependency by integrating the basic insight of the Prebisch-Singer hypothesis into an institutionally-consistent monetary framework. The model implies that the narrow policy space in the short run is overwhelmed by the falling FX supply in the long term - hence the long-term FX constraint. This constraint, moreover, prevents complete adjustment as predicted by the reflux mechanism. Although Barbados is the case study - given its recent program with the IMF - the model of monetary dependence is applicable, in general, to small very open developing countries. The econometric results indicate tenuous support for the monetarist theory, but stronger evidence in favor of the monetary dependency theory. Consistent with the prediction of latter theory, the trade-weighted American dollar exchange rate and its conditional volatility are the strongest determinants.
\end{abstract}

KEY WORDS: foreign exchange market pressure, reflux mechanism, center-periphery, bank liquidity

JEL CODES: F30, F31, F40, O11

*This paper was prepared for the 50th Annual Monetary Studies Conference, Barbados, November $6-8$, 2018. The paper benefitted from helpful comments by participants and Collin Constantine. The views expressed in this paper in no way represent those of the Central Bank of Barbados.

\section{INTRODUCTION}

Barbados has maintained a fixed exchange rate since 1975. This requires that the Central Bank of Barbados hold sufficient foreign exchange reserves to maintain credibility of the peg against the United States dollar. In recent years, however, the Central Bank of Barbados has seen a decline in its level of foreign reserves (IMF 2018). The IMF - in its recent Article IV negotiations with that country - notes that international reserves continue to fall in spite of improvement in the current account balance. The IMF urges Central Bank of Barbados (CBB) to phase out direct financing of central government in an effort to refocus monetary policy towards supporting the 
fixed exchange rate. The Fund also urges the relaxation of liquid asset requirements that commercial banks must hold.

In general, the IMF and several observers attribute the cause of the decline of foreign reserves to the expansion of the monetary base; in particular, the direct financing of central government by the $\mathrm{CBB}$ is often cited as the pivotal reason for the loss of foreign exchange. The expansion of the monetary base is seen as evidence of money printing. We argue that this interpretation comes from the orthodox theories of the monetary approach to the balance of payments and the absorption approach. Policy recommendations to date have been motivated mainly by these two standard theories. Present policies involve cutting government spending and the size of the civil service, as well as recommendations to have commercial banks demand less liquid assets in the form of domestic government securities. The rating agencies - namely Standard and Poor and Moody's - downgraded Barbados' several times since 2000 and more recently in 2017 and 2018. The agencies cited the declining foreign exchange reserves, the expansion of base money and the excessive domestic debt.

We are skeptical, however, regarding the conventional explanation of the decrease in CBB's international reserves. The expansion of domestic currency debt reflects the structural constraints a small economy such as Barbados faces in the global monetary system. Central banks in economies with a peripheral currency cannot earn excessive seignorage via the issue of money at home. This is because the demand for the peripheral currency is limited to the domestic demand. Nevertheless, central banks in the periphery can maintain some wiggle room, albeit limited, by balancing the demand for foreign currency assets and one-sided sales of domestic currency debt to oligopolistic banks and other institutional buyers. The first attempt to measure this wiggle room in the case of Barbados was done by Worrell (1995). Moreover, the domestic financial institutions often purchase the domestic government security because they cannot obtain all the foreign currency in any given time period to meet demand for foreign assets. In other words, the inability to get foreign exchange in the short term acts as a friction restricting the demand for foreign assets; hence, the banks hold on to the non-remunerated excess reserves and buy the local security, thus accounting for the demand for interest-earning excess liquid assets (typically domestic treasury bills). This is why all the excess non-remunerated reserves are not eliminated via the automatic Nurkse-ian reflux mechanism as outlined by Lavoie (2001). In the case of neighboring Guyana, for example, the banks have a tendency to purchase excess 
liquid assets - primarily domestic treasury bills - when there is a shortage of foreign currency and make investments in foreign assets when there is a surplus of foreign exchange in the local market (Khemraj 2009). Therefore, the demand for government securities reflects the persistence of the foreign exchange constraint or friction. The central bank is constantly balancing the demand for foreign exchange and the private sector's demand for treasury bills given the friction $^{1}$.

The domestic debt securities are crucial for preventing complete dollarization. In this sense, therefore, the sovereign domestic debt is the outcome of a dependent monetary system, and not always the product of a reckless government. Monetary dependency means that there is incomplete freedom in policy choice given that the demand for the country's currency is restricted at its borders. Dependent monetary economies do not possess a globally acceptable currency, their terms of trade tend to deteriorate over time, and fiscal and monetary policies are severely restricted by the need to maintain a stable exchange rate. The paper defines dependency in terms of its restriction on development possibilities, and not as an explanation of historical or continuing underdevelopment (Dixon-Fyle 1978). Moreover, dependent monetary economies would tend to have peripheral currencies and their banks and citizens would have a high propensity to invest in foreign assets (Thomas 1965). The economies possessing peripheral currencies will tend to face gradual dollar encroachment and perhaps complete dollarization; and inflation targeting is impossible (McKinnon 2000). The debt cycles of countries in the periphery can be determined by the terms of trade (Coelho and Perez-Caldentey 2018).

The contributions of this paper are as follows. Firstly, it presents a simple model showing that the accumulation of domestic debt is the result of leaning against a deteriorating terms of trade. Therefore, the paper presents a monetary model with a flavor of Prebisch-Singer; hence, a model of curtailed policy space under monetary dependency. It is a center-periphery model, but speaks more of a central bank policy model that allows for short-run policy wiggle room in a fixed exchange rate economy. Secondly, we look at foreign exchange market pressure (EMP) under a fixed exchange rate economy. The topic of EMP has been actively studied over the years. For example, see the work done by Gevorkyan (2017) and Aizenman and Hutchison

\footnotetext{
${ }^{1}$ One might ask why the banks continue to support the fixed exchange rate given the foreign currency shortage in the presence of non-remunerated excess reserves. The answer has to do with the large portfolio of outstanding domestic-currency loans. Rapid devaluation would result in steep inflation pass-through, thus depleting the real value of loans.
} 
(2012). We tweaked their measure of EMP by considering the foreign exchange reserves of the central bank relative to the net foreign assets (NFAs) held by commercial banks.

Thirdly, we test using various time-series econometric specifications the monetary approach, the dependency approach and a hybrid model. Although the econometric results find evidence in support of both monetary approach and dependency approaches, the evidence is much more consistent with the latter than the former. The American dollar trade-weighted exchange rate (not the Barbadian trade-weighted exchange rate) is the strongest determinant of the EMP. This implies that Barbados' de facto exchange rate is the trade-weighted rate of the United States; hence, the dependency status. The conditional volatility of the trade-weighted rate produces a strong precautionary response as well.

Finally, to complete the study of EMP, we estimate an empirical model of net foreign assets (NFAs) of commercial banks. The main determinants are the trade-weighted dollar rate and the cash or liquid reserves of commercial banks. The conditional oil price volatility, instead of the abovementioned volatility, is the main precautionary variable for commercial banks. We also found cointegrating relationships, better than or equaling the five percent level, for the monetary dependence model, hybrid model and NFA of commercial banks. The long run or cointegrating relationship for the monetary approach is significant only at the ten percent level.

The paper is organized as follows. Section 2 critically outlines the conventional approaches to the balance of payments and our new model of EMP. Section 3 looks at charts of recent developments in crucial monetary and macroeconomic variables. Section 4 presents econometric tests of the competing theories and section 5 concludes.

\section{THREE THEORIES OF EMP}

This section outlines three theories of the balance of payments or EMP. The two conventional approaches are first outlined and then our theory of monetary dependency. The absorption and monetary approaches to exchange rate determination are well known; therefore, we will not spend substantial time here explaining them. We sketch the core ideas as illustrated by Jha (1994). The essential idea of the absorption approach is a loss of international reserves can be explained as follows.

$$
\Delta F=X-M=Y-(C+I+G)
$$

Domestic absorption is $A=C+I+G$ 
The change in central bank's international reserves $(\Delta F)$ is positive once $X-M>0$ and negative when $X-M<0$. The source of the current account deficit comes from the fact that $A>Y$. Arresting the deficit and therefore the loss of foreign reserves requires decreasing $G, I$ or $C$. The usual view is to reduce $G$, which requires decreasing central bank financing to government and cutting employment in the civil service.

The monetary approach shows more explicitly the connection between the monetary base and $\Delta F$. It also combines the current and capital accounts of the balance of payments as follows. $\Delta F=X-M+i_{f} I_{f}+R+K=\Delta M-\Delta D$

In identity equation $2, i_{f}$ is the foreign interest rate $I_{f}$ is foreign investments by domestic residents. The symbols $R$ and $K$ represent remittances and net FDIs, respectively. $\Delta D$ represents the change in domestic credit and $\Delta M$ the change in the monetary base. Rewriting identity 2 gives the basic relationship of the monetary approach, which says that the expansion of monetary base is the result of increasing $\Delta F$ and $\Delta D$. Since the Central Bank of Barbados is experiencing falling foreign reserves, the source of the monetary expansion must come from increasing domestic credit. Indeed, this is the argument that is made.

$$
\Delta F+\Delta D=\Delta M
$$

However, we have to add a behavioral equation to this identity relationship. Assume the money market is in equilibrium when $M=L(Y, P, i)$ and the following standard partial derivatives hold: $L^{\prime}(Y)>0, L^{\prime}(P)>0$ and $L^{\prime}(i)<0$; where $Y=$ domestic income, $P=$ price level and $i=$ domestic interest rate. It follows then that the core prediction of the monetary approach is given by equation 4. It says that the central bank will experience falling foreign reserves if domestic credit is expanding at a faster rate than money demand. Moreover, a rise in domestic income will increase money demand and therefore create a surplus. The same happens if there is an increase in the price level. However, a rise in domestic interest rate, ceteris paribus, creates a deficit and therefore a reduction in $\Delta F$. This is all dependent on the idea that domestic and foreign assets are perfect substitutes. Importantly, also, the monetary approach depends on a stable money multiplier. The data in the next section clearly show that as Barbados' monetary base expanded, the multiplier declined significantly, thereby indicating that the central bank's financing of government spending was not completely reflected in the broad monetary 
aggregates. Therefore, CBB's advances and concomitant increase of the monetary base cannot be the only explanation of the fall in international reserves.

$$
\Delta F=L^{\prime}(Y) \Delta Y+L^{\prime}(P) \Delta P+L^{\prime}(i) \Delta i-\Delta D
$$

\section{Monetary Dependency}

The earliest exploration (in the Caribbean) of how commercial banks and the central bank operate in a dependent monetary arrangement was done by Thomas (1965). This paper can be seen in the spirit of that framework. The model shows that when a small economy is faced with external constraints, the public debt (such as treasury bills and other central bank securities) will rise. These securities are often held in excess of requirements; hence, the tendency for commercial banks to hold excess liquid assets. It should be noted that the domestic and foreign security are not perfect substitutes. Residents require foreign currency before they can buy foreign assets. The hard currency may not be available at every moment there is a demand. Often buyers would need to wait their turn. Hence, the limited foreign exchange at any moment constraints the demand. This is the source of an important friction that prevents foreign and local securities from being perfect substitutes.

The demand for the stock of foreign exchange is given by equation 5 . This represents the demand by commercial banks and other domestic investors in foreign currency assets. As is typical of these specifications, and invoking the ceteris paribus condition, the demand is inversely related to the expected exchange rate, $s^{e}$. Note, for the rest of this paper we use an indirect quote whereby the price of the US\$ is in local currency: B $\$ / U S \$$. The opposite happens when the expected rate rises. The task of the monetary authority, which fixes or manages the exchange rate, is to get the expected rate in line with the target rate, $s^{e}=\bar{s}$. The price of exports $\left(P_{X}\right)$ acts as the scale variable in the equation. Increase in the index of export prices engenders a transaction demand for the stock foreign currency. This means the country is in a position to demand more foreign assets (and goods) when $P_{X}$ increases.

$$
F_{D}=F_{0}-\beta_{1} s^{e}+\beta_{2} P_{X}-c B
$$

Our essential contribution is the addition of the stock of domestic-currency bonds, $B$; typically an official security issued either by central government or the central bank for 'mopping up excess reserves'. The 'mopping up' story is the conventional view more in line with monetarist thinking, which holds that reserves determine loans. However, since interest rates are sticky given oligopolistic banking and no secondary money market exists, quantities adjust more 
readily, not prices or interest rates. Hence, we propose that there is an inverse relationship between $F_{D}$ and $B$; whereby the intensity of the relationship is determined by the size of the parameter $c$. This is because the outstanding quantity of sovereign national bonds is supplied for the purpose of displacing some of the demand (emanating from residents) for foreign-currency assets. In other words, the central bank sells these securities to commercial banks in order to create a domestic-driven profit opportunity instead of profits from foreign securities and from making the foreign exchange bid-ask spread too wide. This is what we call the compensation mechanism, which is institutionally different from the automatic or private bank-driven compensation hypothesis described by Lavoie and Wang (2012) and Lavoie (2001). The parameter $c$ measures the compensation intensity. The size of $c$ also depends on the required transaction cost associated with switching excess cash into foreign-currency assets. Higher transaction costs imply a steeper curve and therefore some more policy space for the central bank to displace the demand for foreign currency with local securities. The idea that transaction costs can provide some policy space for independent monetary policy, even under fixed exchange rate, was presented by the former Governor of Central bank of Barbados in an early academic piece (Worrell 1995). In that paper, Worrell augmented the uncovered interest parity equation with a term for transaction costs, which create a friction restricting capital flows when domestic interest rate changes relative to the foreign rate.

Another factor accounting for the imperfect substitutability is the fact that the central bank targets the exchange rate - a fixed rate in the case of Barbados - and by doing so quarantines foreign currencies from the private sector. Hence, to maintain the exchange-rate target, the monetary authority must not only maintain a credible amount of international reserves, but also feed the private banks with an alternative opportunity in the national currency to make profit. The two must go together in order to use the exchange rate target as the anchor.

Furthermore, the parameter $c$ is not the sterilization coefficient. The process of sterilization, as explained by the conventional textbooks, requires an institutional set up which allows two-sided open market operations. The central bank must be able to buy or sell, symmetrically if needed, the net domestic assets in response to the opposite change in its net foreign assets. This is clearly not the case in Barbados or in most developing and even relatively more advanced emerging market economies. On the other hand, compensation occurs mainly through one-sided sales of treasury bills by the central bank to the commercial banks. These one- 
sided sales are supported by the stylized facts - primarily the excess liquid assets that commercial banks hold (see Khemraj 2014). In a symmetrical sterilization system this should not hold and the excess reserves (and excess liquid assets) would be eliminated in the long-term. Interestingly, Worrell (1997) notes that 'open market operations' to be primarily sales of treasury bills in Barbados. He observed that the banks tend to buy domestic securities because they have non-remunerated excess reserves in all periods. Exactly what determines the non-remunerated excess reserves is beyond the scope of this study. Nevertheless, we think mentioning two factors would be helpful. Firstly, government payments from its account at the central bank is an important source given the persistent fiscal deficits ${ }^{2}$. Secondly, over the long term, the monetary authority buys foreign currencies from nationals more than it sells, thereby injecting net cash into the banking system.

The reflux principle is another idea we should clarify at this point. If monetary reflux holds, then the non-remunerated excess reserves should be used to repay the central bank in the case of an overdraft economy ${ }^{3}$. The stylized facts illustrate that non-remunerated excess reserves, as well as interest-earning excess liquid assets are persistent. We listed two of their sources above. As noted earlier, displacing the excess cash requires the one-sided sales of interestearning securities. However, the adjustment which takes place in developing countries is different from than that implied by the asset-based and overdraft systems, so clearly outlined by Lavoie (2006). The commercial banks (and other private economic actors) in countries with peripheral currencies do not use the excess cash to repay loans, but to build up their portfolio of foreign-currency assets. Therefore, the monetary reflux occurs in hard-currency flight, not the repayment of debt.

\footnotetext{
${ }^{2}$ Among the other crucially important points raised by Bell (2000), she notes that this channel is a source of excess reserves in the case of the United States. Furthermore, for us to understand the source of excess reserves, the central bank's balance sheet must include government deposits on its liability side, as illustrated by Lavoie (2001). However, it should be noted that the role of excess liquidity and non-remunerated excess reserves is different in our interpretation of the compensation thesis. Non-remunerated excess reserves should be eliminated automatically under the Nurkse-ian automatic adjustment - since private banks seek to repay debt owed to central bank - as explained by Lavoie (2001) and Lavoie and Wang (2012). In our interpretation, excess reserves are persistent owing to the foreign exchange constraint and policy decision of central bank not to neutralize all excess by selling the interest-earning security.

${ }^{3}$ For an explanation of the reflux principle see Lavoie (2001) and for historical context of the idea see (Vernengo and Rochon 2001). A comprehensive explanation of asset-based versus overdraft economies can be found in Lavoie (2006).
} 
Moreover, Barbados and many such economies are neither completely asset-based nor overdraft economies. The banks obtain reserves via government spending out of its deposits at the central bank and when the monetary authority buys foreign currencies from nationals (and others) inside the country. They cannot use their national currencies to buy American dollars or euros in London or New York. They have peripheral and not hegemonic fiat currencies. Hence, the official payments at home create the non-interest cash reserves, often in excess of requirements given the logic of persistent fiscal deficits. The underdevelopment or non-existence in most cases of the secondary money market means that the economies are not asset-based. Most times the banks do not (or cannot) sell treasury bills to obtain reserves. The assets are held until they mature. Once the central bank targets the exchange rate the net purchase from the local market will always be positive in the long term given the need to maintain a credible amount of international reserves. One point that is often ignored in the mainstream literature is the fact that these interest-earning excess liquid assets serve the purpose of stabilizing the commercial banks because many of them are sold in markets which do not have forward speculators (Khemraj $2014)^{4}$.

Equation 6 indicates the supply of foreign exchange (in stocks) to the financial sector. The supply, assuming everything else is constant, is positively related to $s^{e}$ as is the typical specification in open economy macroeconomics. The index of import prices $\left(P_{M}\right)$ acts as a unit cost in the supply function. Therefore, an increase in the import price decreases the supply of the stock of foreign exchange at any given moment. We assume a positive relationship between $F_{S}$ and $B$. This is because selling the domestic securities to locals creates room for more foreign currencies to be available to importers and the banks. The parameter $d$ measures the extent to which the domestic treasury bills free up foreign exchange supply to the banks. In other words, supplying securities to nationals frees up foreign exchange to the banks and importers. We postulate that $d$ is a smaller parameter relative to the absolute value of $c$. The logic for this has to do with the long-term deterioration of the terms of trade. The decline in the terms of trade implies that the debt-elasticity of supply of foreign currency should fall over time. In other words, the positive response of foreign currencies given the supply of domestic debt to the banks

\footnotetext{
${ }^{4}$ Hence, at least the possibility exists - but has been largely ignored given the persistence of monetarist interpretation - for governments in underdeveloped countries to meet some social obligations in spite of the ultimate foreign exchange constraint associated with a country with a peripheral currency.
} 
should fall in the long run in spite of the wiggle room we mentioned earlier. $F_{0}$ and $\bar{F}$ are constants.

$$
F_{S}=\bar{F}+\beta_{3} s^{e}-\beta_{4} P_{M}+d B
$$

Given that we are concerned with a fixed exchange rate system (or a managed one), we can replace $s^{e}$ with $\bar{s}$. Since $\bar{s}$ is the policy target, it becomes an exogenous variable. Dependent economies cannot determine either $P_{X}$ or $P_{M}$ since they are price takers on both the export and import sides. This means $P_{X}$ and $P_{M}$ are exogenous variables. This allows us to solve for the two endogenous variables $B^{*}$ and $F^{*}$. We further invoke the Prebisch-Singer hypothesis in order to restrict the size of the parameters and take note of the fact that the Terms of Trade, TOT $=P_{X} / P_{M}$. The TOT would tend to decline in the long run in dependent developing economies. This is consistent with the literature (see Ziesemer 2014, Erten 2011, Etren and Ocampo 2013). The following parameter restriction is therefore consistent with the Prebisch-Singer thesis $\beta_{2}<-\beta_{4} \mid$. This restriction implies that both $P_{X}$ and $P_{M}$ could rise in the long run, but the rate of growth of $P_{M}$ will be faster than $P_{X}$, thus accounting for the decline of the TOT.

Solving for equilibrium $B^{*}$ and $F^{*}$ and setting $s^{e}=\bar{s}$ will produce equations $7 \mathrm{a}$ and $7 \mathrm{~b}$.

$$
\begin{aligned}
& B^{*}=\frac{\left(F_{0}-\bar{F}\right)+\beta_{2} P_{X}+\beta_{4} P_{M}-\left(\beta_{1}+\beta_{3}\right) \bar{s}}{c+d} \\
& F^{*}=\bar{F}+\beta_{3} \bar{s}-\beta_{4} P_{M}+d\left(\frac{\left(F_{0}-\bar{F}\right)+\beta_{2} P_{X}+\beta_{4} P_{M}-\left(\beta_{1}+\beta_{3}\right) \bar{s}}{c+d}\right)
\end{aligned}
$$

These equations allow us to analyze the outcome in outstanding domestic debt and foreign exchange in the long run when the Prebisch-Singer condition holds. This requires analyzing four partial derivatives and checking the signs to calculate the net effect. First, we look at the partial effect of $P_{X}$ and $P_{M}$ on $B^{*}$.

$\frac{\partial B^{*}}{\partial P_{M}}=\frac{\beta_{4}}{c+d}>0$

$$
\frac{\partial B^{*}}{\partial P_{X}}=\frac{\beta_{2}}{c+d}>0
$$

Equations $8 \mathrm{a}$ and $8 \mathrm{~b}$ show positive partial effects on $B^{*}$. It follows that these two foreigndetermined prices will expand domestic securities. Furthermore, it explains why there is significant levels of excess liquid assets in the banking sector of small dependent developing 
economies. The Barbados banking sector is also very liquid, which indicates the tendency of government to lean against global headwinds in order to pursue domestic social objectives.

The next task is to explore the foreign exchange outcome in the long run under the Prebisch-Singer hypothesis. The partial effects of $P_{X}$ and $P_{M}$ on $F^{*}$ are expressed by equations 8c and $8 \mathrm{~d}$. We have two opposing effects. Equation 8a shows that higher export prices will increase the foreign exchange, while $8 \mathrm{~b}$ indicates the opposite effect since $0<d /(c+d)<1$. Note also that $d$ and $\beta_{2}$ are small numbers compared with $c$ and $\beta_{4}$. This means that the negative partial effect will be greater than the positive one $\left(\left|\partial F^{*} / \partial P_{M}\right|>\partial F^{*} / P_{X}\right)$. Therefore, we can conclude the foreign exchange situation becomes binding in the long run in spite of the short run policy space of selling $B$ to compensate commercial banks.

$$
\begin{aligned}
& \frac{\partial F^{*}}{\partial P_{X}}=\frac{d \beta_{2}}{c+d}>0 \\
& \frac{\partial F^{*}}{\partial P_{M}}=\beta_{4}\left(\frac{d}{c+d}-1\right)<0
\end{aligned}
$$

Figure $1 \quad$ Foreign and domestic securities under monetary dependence

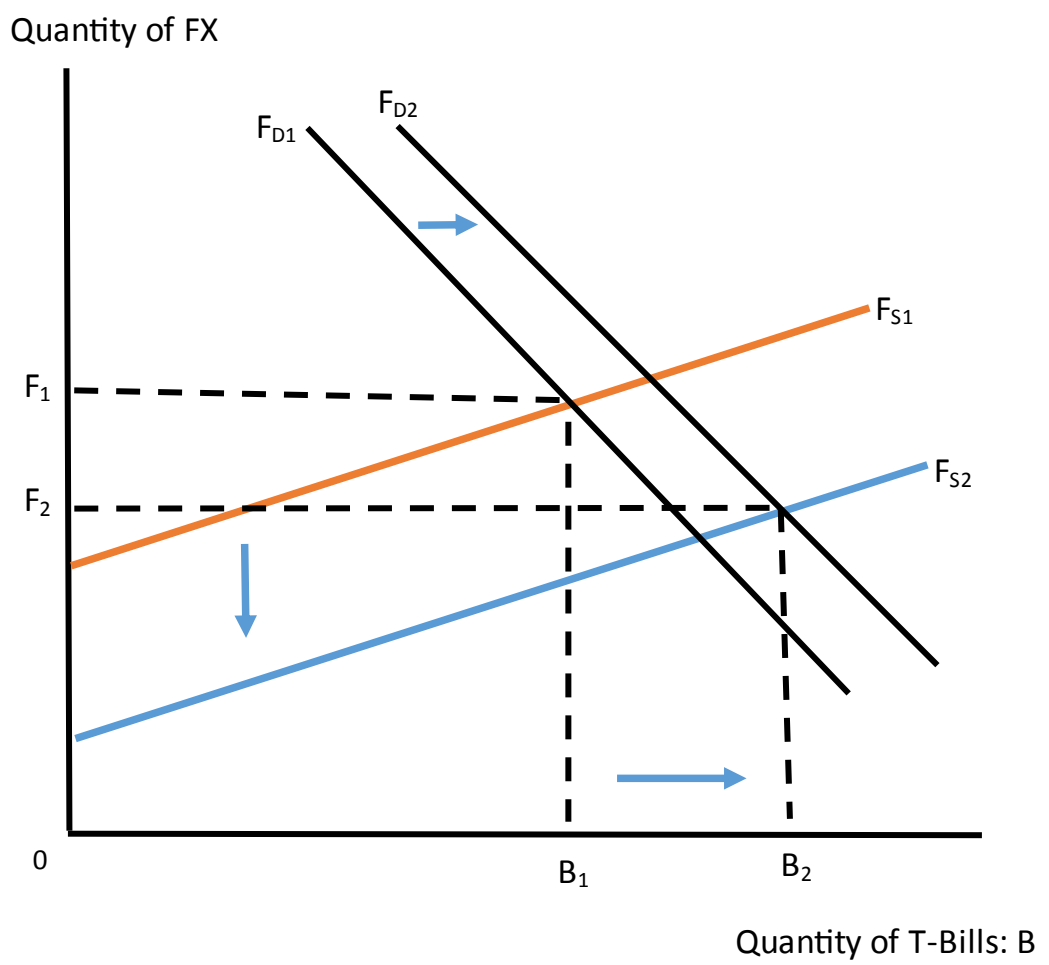


Figure 1 summarizes the results. Over a long enough period of time, $P_{M}$ will grow at a faster rate compared with that of $P_{X}$, thus worsening the terms of trade. When both of $P_{X}$ and $P_{M}$ are increasing over time we can expect that the $F_{S}$ curve will shift downward from $F_{S 1}$ to $F_{S 2}$ and the $F_{D}$ curve will shift outward from $F_{D 1}$ to $F_{D 2}$. In keeping with the assumed parameters, the $F_{D}$ curve must be relatively steeper than $\mathrm{F}_{\mathrm{S}}$ (in terms of absolute value). Also, the shift in the $\mathrm{F}_{\mathrm{S}}$ curve should be larger than that of $\mathrm{F}_{\mathrm{D}}$ given that $\beta_{2}<-\beta_{4} \mid$. The result is an expansion of the stock of domestic securities and a long-run tightening of the availability of foreign exchange . As $^{5}$ noted previously, this expansion of sales of domestic securities is meant to motivate demand for domestic financial assets instead of foreign-currency assets. Finally, the figure shows that the ratio $\Delta F / \Delta B \rightarrow 0$ over time as both $P_{X}$ and $P_{M}$ increase. In other words, the FX constraint is binding in the long term for dependent economies. It means that the debt-elasticity of FX supply also declines in the long run. Perhaps this is why Barbados finds itself in need of an IMF program every decade or so.

\section{RECENT TRENDS}

These charts provide initial clues into possible factors accounting for the decline in international reserves. They indicate monthly data from 2000: Jan to 2017: Dec. The data were sourced from Central Bank of Barbados and only the FDI as a percent of GDP was obtained from the World Development Indicators.

The first chart observes the trends in international reserves, as well as the total net foreign assets (NFAs) of commercial banks. It also shows the percent of central bank FX reserves compared with NFAs of commercial banks. The chart indicates a clear divergence between foreign assets held by CBB and all commercial banks. The former's foreign reserves remained virtually flat for the sample period, but took on a distinctive downward trajectory since the first quarter of 2013. On the other hand, commercial banks have tended to increase their foreign currency assets throughout the period, but with a steeper increase since the third quarter of 2011. The bars indicate the percent, which is on the right axis, of CBB's FX reserves to commercial banks' NFAs. There appears to be a clear structural break in the percent of FX reserves CBB

\footnotetext{
5 We do not present the devaluation outcome because the study of devaluation requires a fully specified macroeconomic model of income distribution, price formation and capacity utilization. Suffice to say, the partial equilibrium presented herein suggests that devaluation will depress domestic assets and foreign exchange in the long term. The latter result depends on whether the $\mathrm{F}_{\mathrm{D}}$ is more responsive to $s^{e}$ than $\mathrm{F}_{\mathrm{S}}$ is to $s^{e}$. We think for dependent developing economies, the partial effect of $\mathrm{F}_{\mathrm{D}}$ relative to $s^{e}$ should be stronger compared with that of $\mathrm{F}_{\mathrm{S}}$.
} 
holds since October 2011. The percent declined precipitously after September 2011 when it stood at 72 percent. By March 2013, the percent of CBB reserves fell to 47 percent and by the end of the review period, December 2017, it fell further to 20 percent.

Figure 1 Foreign reserves of CBB and NFA of commercial banks

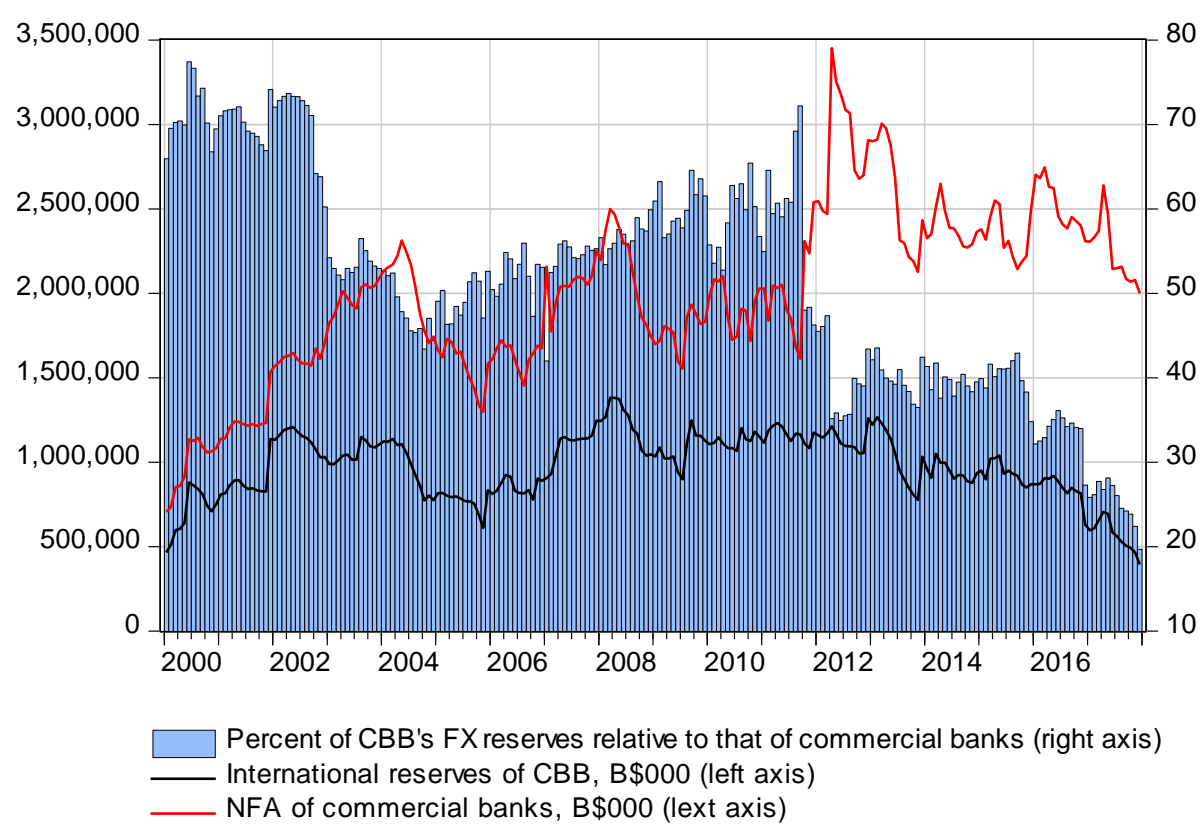

Overall, both series declined since 2012, thus indicating the overall foreign exchange pressure. However, from the middle of 2012 to around June 2017, the NFA of commercial banks stabilized around $\mathrm{B} \$ 2.5$ billion (or US $\$ 1.25$ billion), even as the central bank saw a continual decline. After the first half of 2017, both banks and CBB experienced steep decline in foreign currency assets. However, the fall in the central bank's position was much more pronounced, causing the percent of $\mathrm{CBB}$ foreign assets relative to that of commercial banks to decline significantly. The charts below indicate possible determinants of the patterns we observed so far.

First, we take a look at total commercial bank loans to the private sector. Since domestic absorption cannot be measured directly, we use bank loans to the private sector as an indirect proxy for domestic demand given that all credit intermediated are demanded. This is illustrated by Figure 2, which also presents the percent international reserves of CBB. There was a steady increase in bank loans from 2000 to June 2004. There was a steep increase in bank credit after 2005 until end of 2008; thereafter remaining relatively flat until September 2011. There was a 
fair amount of volatility from October 2011 until the end of 2012, a period that marked the precipitous drop in central bank's percent of FX reserves. Since January 2013, bank credit has contracted gradually.

Figure 2 Stock of commercial-bank loans to private sector

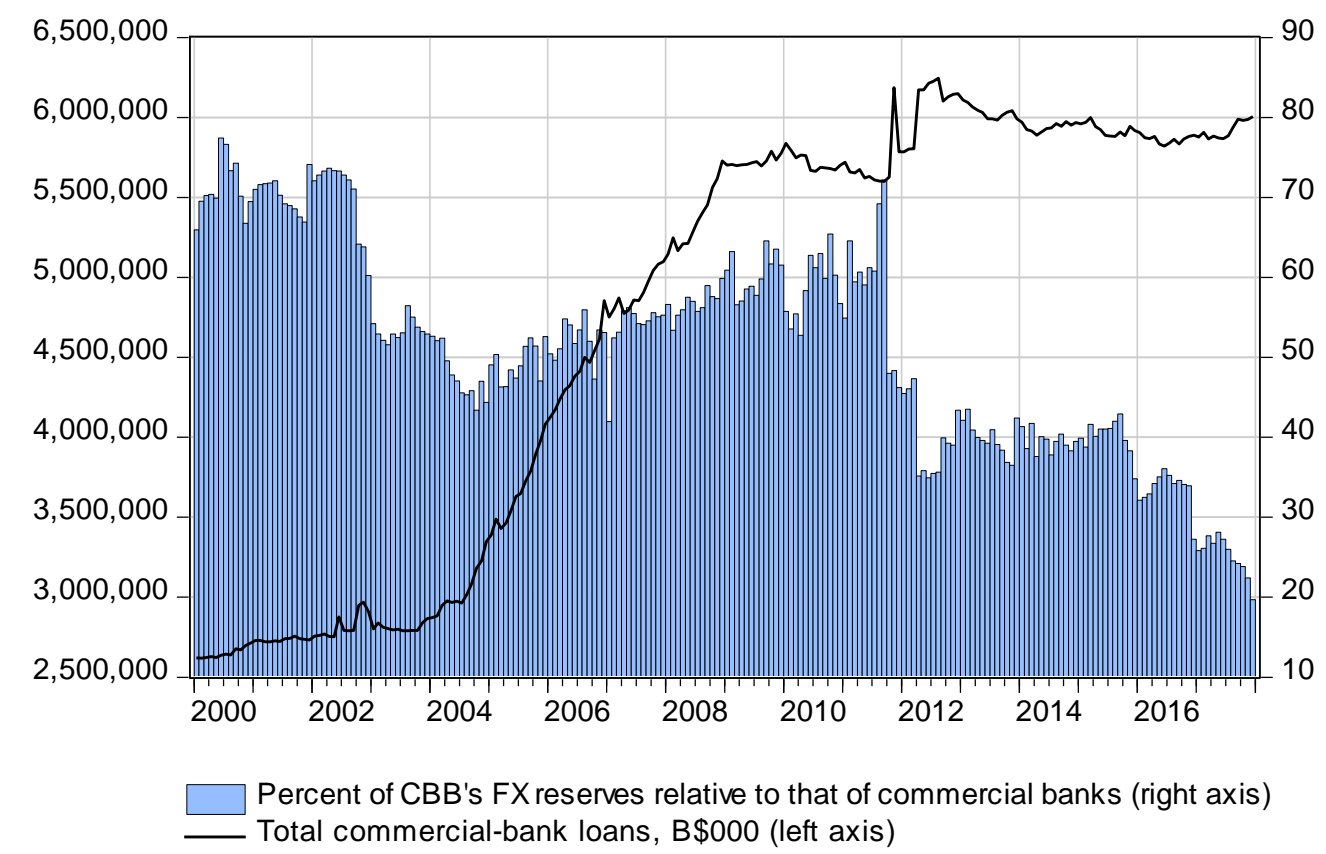

Figure 3 explores recent trends in the rate of inflation, the money multiplier and the monetary base. From 2000 to 2013 the monetary base displayed a stable long-term upward trend as we would expect in an economy with growing transaction volume. However, there is a clear break in the trend after the first quarter of 2014 when base money expanded significantly. As the base expanded steeply, the Barbados economy would enter into a period of negative inflation. The multiplier started its steep decline from March 2014. As noted earlier, the percent of central bank reserves would fall steeply much earlier. These data patterns are not consistent with the idea that the expansion of the monetary base triggered the steep collapse in CBB reserves. The findings displayed by Figure 3 is consistent with the endogenous money thesis. Barbadian economist of yesteryear, Wendell McLean, showed that the monetary base of small open economies in the Caribbean is endogenous (McLean 1985, 1998). He observed empirically that 
the base is responsive to changes in foreign exchange payments in the Barbadian context. Of course, the endogenous money hypothesis is also a cornerstone of post-Keynesian economics in both bank and asset-based systems.

Figure 3 Inflation, multiplier and monetary base

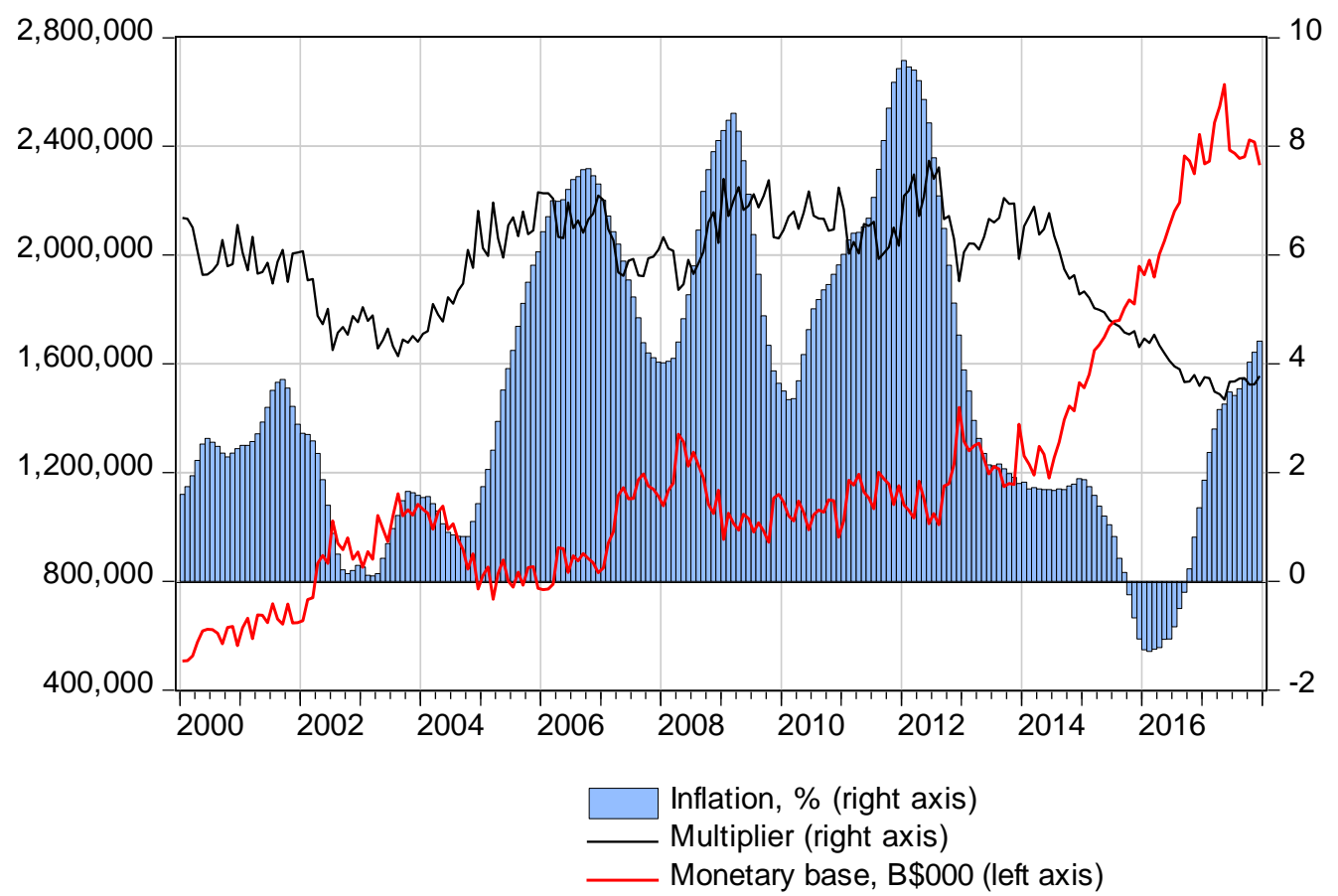

A few other trends are worth mentioning, but we will not present another chart in the hope of saving space. It should be noted that the fiscal deficit as a percent of GDP, for the review period, reached its peak at 10.1 percent in 2013. However, the deficit declined continually after 2013 to reach 4 percent of GDP by 2017. The net FDI flow collapsed in 2013 to -0.2 percent. It did similar in 2004 when it was -0.3 percent. However, net FDIs increase to 12 percent of GDP in 2014 and subsequently declined to an average around 6 percent for 2015, 2016 and 2017. For the entire review period, public sector wage as a percent of GDP was around 8.2 percent. The highest amount of public sector wage occurred in 2013 and amounted to 10.1 percent of GDP. The wage bill as a percent of GDP declined marginally by 2017 when it reached 9.1 percent. These trends do not appear to be the trigger for the sudden rise in EMP around late 2011 to 2012. 


\section{EMPIRICAL ANALYSIS}

From the theoretical analyses we have two conventional explanations: the absorption approach and the monetary approach. Our data set allows us to test more explicitly the monetary approach. The monthly financial and monetary statistics can only indirectly test the absorption approach. The monetary dependence model is the unconventional explanation. Two econometric models are estimated to search for long-run relations as implied by the two theories. A hybrid model, combining the two approaches, is also estimated. These three models are intended to estimate the possible factors determining the level of foreign reserves of $\mathrm{CBB}$. A fourth model is estimated to investigate probable determinants of NFAs of commercial banks.

The peril of estimating level-based relationships using time-series data is well known. Even cointegration tests for long-term level relations might also uncover spurious relations (Moosa 2017). Therefore, we rely on economic theory, intuition and knowledge of Barbadian economic structure to set up the models to study exchange market pressure in Barbados. The empirical strategy estimates four separate level models, as well as the short-term counterparts, instead of a single EMP model. The single model would likely result in identification problems given the competing theories and variables. For example, it is clear that an opportunity cost variable, such as the domestic prime lending rate, would determine the commercial banks' demand for NFA, but not the central bank's demand for international reserves. The excess reserves of the commercial banks should increase their demand for NFAs as found by Bakker (1993) and Khemraj (2009), but not the demand for central bank's FX reserves and so on.

The first model to be estimated is in the spirit of the monetary approach and somewhat in the absorption approach. The main determinants of CBB's demand for FX reserves would be (i) a foreign interest rate that captures a speculative dimension of demand (which we proxy by the 3-month US Treasury bill rate), (ii) a precautionary motive (which is measured by the negative rating outlook of Moody's and Standard and Poor and volatility), and (iii) factors exerting downward pressure on demand for foreign reserves. The latter would include variables consistent with the monetary approach and the monetary dependency thesis.

The general ARDL model which nests the competing hypotheses is expressed as follows $\log F_{t}=\varphi_{1}+\varphi_{2} N+\sum_{i=1}^{p} \lambda_{i} \log F_{t-1}+\sum_{i=0}^{q} \alpha_{i} \log r_{t-i}+\gamma Z_{M}+\beta Z_{D}+\varepsilon_{t}$ Where $F=$ central bank's holding of FX reserves; $N=1$ for negative outlook from Moody's or Standard or Poor and 0 otherwise; and $r=$ three-month United States Treasury bill rate. The 
vector $Z_{M}$ includes variables at different lags unique to the monetary approach and perhaps tangentially to the absorption approach.

$Z_{M}=\left(\begin{array}{l}\log A_{C} \\ \log L_{G} \\ \log L_{U} \\ \log L_{P}\end{array}\right)$

$A_{C}=\mathrm{CBB}$ 's monetary advances to the central government; $L_{G}=$ commercial bank loans to central government; $L_{U}=$ commercial bank loans to public utilities; and $L_{P}=$ total commercial bank loans to the private sector. The row vector $\gamma$ includes contemporaneous and lagged elasticities to be measured given the double-log specification.

On the other hand, the vector $Z_{D}$ includes variables at different lags that are unique to our conceptualization of monetary dependency; namely, the country's reserve target is restricted by possessing a peripheral currency. $S_{T}=$ the United States trade-weighted exchange rate; $P_{O}=$ Brent price of oil; and VOil measures the oil price volatility; and $S V$ represents the volatility of the trade-weighted dollar exchange rate. Since, Barbados has a fixed exchange rate against the dollar, the trade-weighted value of the dollar should matters for the availability of foreign exchange. This exchange rate measures the strength of the dollar against the Euro Area, Canada, United Kingdom and other main trading partners of the United States. We expect that an appreciating trade-weighted exchange rate should reduce the flow of non-American tourists into Barbados and therefore the availability of foreign currencies. Indeed, American tourists account for just about 14 percent of all tourists going to Barbados. Also, since capital goods are priced in terms of dollars, an appreciation of the rate would also increase the cost of imports and reduce the amount of FX available to the private sector and CBB. A depreciation of the dollar should have the opposite effect. The row vector $\beta$ includes elasticities.

$Z_{D}=\left(\begin{array}{l}\log S_{T} \\ \log P_{O} \\ \text { oilV } \\ S V\end{array}\right)$

The general ARDL model for estimating the commercial banks' demand for NFA can be written as:

$\log N F A_{t}=\phi_{0}+\sum_{i=1}^{p} \phi_{i} \log N F A_{t-i}+\eta X$ 
Where,

$$
X=\left(\begin{array}{l}
\log \left(r_{L}-r\right) \\
\log P_{O} \\
\log L I Q \\
\log S_{T} \\
\text { oilV } \\
S V \\
N
\end{array}\right)
$$

The vector $X$ includes the variables of different lags so as to make it a true ARDL. The row vector $\eta$ includes the elasticities on the contemporaneous and lagged variables. The opportunity cost of demanding NFAs is making loans at home. This is measured by prime loan rate in Barbados, $r_{L}$, which would also indicate the speculative motive once we subtract the foreign interest rate mentioned earlier. One unique factor that should influence the demand for NFAs by banks is the amount of excess reserves in the banking system (Khemraj 2009, Bakker 1993). We do not have the excess reserves data, but we do have total reserves, which is indicated by $L I Q$. The other variables postulated to affect commercial banks' NFAs were discussed earlier.

The analysis is done using monthly data from Jan: 2000 to Dec: 2017. Most of the statistics came from Central Bank of Barbados. However, the three-month US Treasury bill, trade-weighted American dollar exchange rate and Brent oil price were obtained from the Federal Reserve Bank of St. Louis (https://fred.stlouisfed.org/). The exchange rate and oil price volatility were measured using a $\operatorname{GARCH}(1,1)$ estimate of mean and variance equations. The negative outlook rating for Moody's and Standard \& Poor comes from Trading Economics (https://tradingeconomics.com/barbados/rating).

The following partial effects are expected to hold. Firstly, we expect CBB advances to central government, and commercial bank loans to public utilities and central government to have a negative effect on the central bank's demand for FX reserves. Secondly, commercial bank loans to the private sector could have either a negative or positive effect. If the domestic absorption effect is great, there should be a negative partial effect or coefficient. On the other hand, if commercial bank loans contribute to growth in the tradable sector and therefore FX earnings, we expect a positive effect. Thirdly, the negative rating outlook dummy variable measures a precautionary effect. It should have a positive partial effect regardless of whether we 
are estimating the monetary model, monetary dependency model or hybrid model. Fourthly, the level of the oil price must have a negative partial effect in the monetary dependency model since it represents a cost of importing. Fifthly, the volatility measures from oil price and tradeweighted exchange rate is expected to have a positive effect on central bank behavior. Higher volatility would induce a precautionary effect on behalf of the CBB. Finally, the trade-weighted exchange rate is postulated to have a negative partial effect on international reserves.

As it relates to commercial banks' demand for NFA, we propose the following partial effects. Firstly, the term $r_{L}-r$ would have a negative effect, all other factors remaining constant. Secondly, the trade-weighted exchange rate will have a negative partial effect. This is because a stronger American trade-weighted rate reduces the flow of hard currencies coming to Barbados. A depreciation will have the opposite effect. Thirdly, LIQ will exert a positive partial effect. The rationale here is once the banks have excess of reserves over the required level, they will buy foreign assets instead of extending loans at home. Fourthly, the volatility measures, as well as the negative rating dummy, should induce a precautionary effect. The reasoning here is banks would require holding more foreign currency assets in uncertain times to meet the business needs of established customers, many of whom also received loans in Barbados from the banks.

We tested for stationarity using the Augmented Dickey-Fuller and Phillips-Perron tests. All the series were found to be I (1), except for the oil price volatility and trade-weighted exchange rate volatility. The conditional volatilities were found to be I (0) or stationary. No series was determined to be I (2). Therefore, we adopted the Pesaran, Shin and Smith (2001) bounds testing approach for estimating the level relationships of the theories. In the case of the monetary approach model, all the variables were I (1) in levels; therefore, we supplemented the bounds test with the Johansen cointegration test.

Table 1 presents the long-run estimates of the three models. The diagnostic tests - given the high p-values - indicate that the models do not suffer from serial correlation or heteroscedasticity. The AIC test indicates the best result for the MD model, followed by the 2.667 for the MA model. The strongest cointegration result occurs for the MD model followed by the HM. In the case of the former the F-Stat. of 5.76 exceeds the upper I (1) bound at the one percent level. The F-Stat $=4.44$ for the HM just marginally exceeds the upper bound one percent critical value of 4.43. The supplemental Johansen cointegration test for the MA model confirms the level relationship according to trace test and the max-eigenvalue test at the five percent 
significance level. The 3-month U.S. treasury bill rate was found to be statistically and economically insignificant in all cases. Therefore, we are not reporting these estimates. The oil price volatility produced mixed results. Therefore, the volatility measure here is the tradeweighted exchange rate.

Table 1 Long-run estimates and diagnostic tests: CBB's demand for foreign reserves

\begin{tabular}{|c|c|c|c|}
\hline \multicolumn{4}{|c|}{ Dependent variable: Log (FX reserves of Central Bank) } \\
\hline Variables & $\begin{array}{l}\text { Long-run } \\
\text { estimates: } \\
\text { Monetary } \\
\text { approach } \\
\text { (MA) }\end{array}$ & $\begin{array}{l}\text { Long-run } \\
\text { estimates: } \\
\text { Monetary } \\
\text { dependence } \\
\text { (MD) }\end{array}$ & $\begin{array}{l}\text { Long-run } \\
\text { estimates: } \\
\text { Hybrid model } \\
\text { (HM) }\end{array}$ \\
\hline $\begin{array}{c}\text { Log (CBB advances to } \\
\text { central govt.) }\end{array}$ & $\begin{array}{c}-0.325 \\
(\mathrm{pv}=0.111)\end{array}$ & - & $\begin{array}{c}-0.220 \\
(\mathrm{pv}=0.125)\end{array}$ \\
\hline $\begin{array}{c}\text { Log (Comm. bank } \\
\text { loans to central govt) }\end{array}$ & $\begin{array}{c}-0.053 \\
(\mathrm{pv}=0.178)\end{array}$ & - & $\begin{array}{c}\text { Economically and } \\
\text { statistically } \\
\text { insignificant }\end{array}$ \\
\hline $\begin{array}{c}\text { Log (Comm. bank } \\
\text { loans to public } \\
\text { utilities })\end{array}$ & $\begin{array}{c}-0.00014 \\
(\mathrm{pv}=0.002)\end{array}$ & - & $\begin{array}{c}-0.254 \\
(\mathrm{pv}=0.043)\end{array}$ \\
\hline $\begin{array}{l}\text { Log (Total loans to } \\
\text { private sector from } \\
\text { comm. banks) }\end{array}$ & $\begin{array}{c}1.672 \\
(\mathrm{pv}=0.015)\end{array}$ & - & $\begin{array}{c}1.274 \\
(\mathrm{pv}=0.037)\end{array}$ \\
\hline $\begin{array}{l}\text { Volatility: Trade- } \\
\text { weighted Ex. rate }\end{array}$ & - & $\begin{array}{c}12.609 \\
(\mathrm{pv}=0.054)\end{array}$ & $\begin{array}{c}13.908 \\
(\mathrm{pv}=0.099\end{array}$ \\
\hline $\begin{array}{c}\text { Log (US\$ trade- } \\
\text { weighted exchange } \\
\text { rate) }\end{array}$ & - & $\begin{array}{c}-6.708 \\
(\mathrm{pv}=0.001)\end{array}$ & $\begin{array}{c}-7.098 \\
(\mathrm{pv}=0.005)\end{array}$ \\
\hline $\begin{array}{l}\text { Negative rating: S\&P } \\
\text { and Moody's (dummy } \\
\text { variable) }\end{array}$ & $\begin{array}{c}0.516 \\
(\mathrm{pv}=0.115)\end{array}$ & $\begin{array}{c}0.339 \\
(\mathrm{pv}=0.114)\end{array}$ & $\begin{array}{c}0.423 \\
(\mathrm{pv}=0.133)\end{array}$ \\
\hline \multicolumn{4}{|c|}{ Bounds cointegration and other tests } \\
\hline $\begin{array}{l}\text { Serial correlation: } \mathrm{LM} \\
\text { test: F-Stat. }\end{array}$ & $\begin{array}{c}0.91 \\
(\mathrm{pv}=0.535)\end{array}$ & $\begin{array}{c}1.06 \\
(\mathrm{pv}=0.395)\end{array}$ & $\begin{array}{c}1.40 \\
(\mathrm{pv}=0.172)\end{array}$ \\
\hline ARCH (12): F-Stat. & $\begin{array}{c}0.73 \\
(\mathrm{pv}=0.723)\end{array}$ & $\begin{array}{c}0.57 \\
(\mathrm{pv}=0.867)\end{array}$ & $\begin{array}{c}1.28 \\
(\mathrm{pv}=0.242)\end{array}$ \\
\hline AIC & -2.667 & -2.581 & -2.709 \\
\hline Bounds test: F-Stat. & $\begin{array}{c}3.78 * *[10 \% \mathrm{I}(0) \\
\text { bound }=2.45 ; 10 \% \\
\mathrm{I}(1) \text { bound }=3.52]\end{array}$ & $\begin{array}{c}\mathbf{5 . 7 6}^{*}[1 \% \mathrm{I}(0) \\
\text { bound }=3.65 . ; 1 \% \\
\mathrm{I}(1) \text { bound }=4.66]\end{array}$ & $\begin{array}{c}\mathbf{4 . 4 4} *[1 \% \mathrm{I}(0) \\
\text { bound }=3.15 ; 1 \% \\
\mathrm{I}(1) \text { bound }=4.43]\end{array}$ \\
\hline \multicolumn{4}{|c|}{$\begin{array}{l}\text { *Significant at } 1 \% \text { level. } \\
* * \text { Significant at } 10 \% \text { level. Since all variables in MA model are I (1), the Johansen tests } \\
\text { was done as a robustness check. It supports the existence of the cointegrating equation. } \\
\text { Both Trace and Maximum Eigenvalue tests support cointegration at } 5 \% \text { level for the MA } \\
\text { model. }\end{array}$} \\
\hline
\end{tabular}


The elasticities for the MA model are relatively small. Central bank advances (money printing) to the central government has an elasticity of -0.325 . Although an economically significant number, it is statistically insignificant with a p-value of 0.111 . The p-value of the money-printing elasticity does not improve substantially in the HM, but it is an economically notable elasticity of -0.220 . Commercial banks' loans to public utilities is statistically significant given the low p-value $=0.002$, but economically insignificant at -0.00014 . The size of the elasticity increases substantially in the HM, where it becomes both economically (elasticity = 0.254 ) and statistically significant at the five percent level ( $\mathrm{p}$-value $=0.043$ ). The most statistically significant variable in the MA model is the total commercial bank loans to the private sector. The high positive elasticity is economically significant as well (1.672 in MA and 1.274 in HM). The positive value suggests that private sector credit has a favorable effect on the tradable sector, which outweighs the absorption effect. Commercial bank loans to central government show little economic or statistical significance.

In the long run, the strongest factor reducing the central bank's FX reserves is the US trade-weighted dollar exchange rate. The elasticity is -6.908 in the MD model and -7.098 in the HM. It is also the most statistically significant explanatory variable in both the MD model and HM with very low p-values of 0.001 and 0.005 , respectively. We were surprised by the large size of the elasticity representing CBB's precautionary response to world exchange rate volatility. This result is also fairly statistically significant. The negative credit rating has the correct sign indicating the precautionary behavior of the CBB across all the models. However, the p-values indicate statistical insignificance since they all exceed the ten percent level.

For completeness Table 2 reports the short-run error correction models. The short-term elasticities tend to make sense. Total loans to the private sector appears to have short-term negative effect on CBB's foreign reserves. This implies the absorption effect holds only in the short run, but not in the long run. The trade-weighted volatility is not significant in the short run. However, the trade-weighted rate continues its strong effect even in the short term with estimates of -0.852 and -0.749 in the $\mathrm{MD}$ and $\mathrm{HM}$, respectively. The negative rating dummy variable is a lot more statistically significant in the short run. Of particular interest here is the sign and statistical significance of the cointegration term, which has the expected negative sign in all the models and is highly statistically significant; hence, confirming that the level relationships are not spurious. 
Table 2 Short-run estimates: CBB's demand for foreign reserves

\begin{tabular}{|c|c|c|c|}
\hline \multicolumn{4}{|c|}{ Dependent variable: $\Delta[\log (\mathrm{FX}$ reserves of Central Bank) $]$} \\
\hline Variables & $\begin{array}{l}\text { Short-run } \\
\text { estimates: } \\
\text { Monetary } \\
\text { approach }\end{array}$ & $\begin{array}{l}\text { Short-run } \\
\text { estimates: } \\
\text { Monetary } \\
\text { dependence }\end{array}$ & $\begin{array}{l}\text { Short-run } \\
\text { estimates: } \\
\text { Hybrid model }\end{array}$ \\
\hline $\begin{array}{ll}\Delta[\log & (\mathrm{CBB} \\
\text { advances to central } \\
\text { govt. })]\end{array}$ & $\begin{array}{c}-0.031 \\
(\mathrm{pv}=0.049)\end{array}$ & 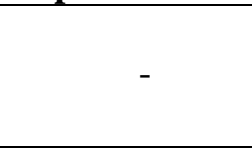 & $\begin{array}{c}-0.029 \\
(\mathrm{pv}=0.031)\end{array}$ \\
\hline $\begin{array}{l}\Delta[\log (\text { Comm. } \\
\text { bank loans to central } \\
\text { govt })]\end{array}$ & $\begin{array}{c}-0.008 \\
(\mathrm{pv}=0.333)\end{array}$ & - & $\begin{array}{c}\text { Economically } \\
\text { and statistically } \\
\text { insignificant }\end{array}$ \\
\hline $\begin{array}{l}\Delta[\log (\text { Comm. } \\
\text { bank loans to public } \\
\text { utilities })]\end{array}$ & $\begin{array}{c}-0.00002 \\
(\mathrm{pv}=0.126)\end{array}$ & - & $\begin{array}{c}-0.034 \\
(p v=0.112)\end{array}$ \\
\hline $\begin{array}{l}\Delta[\log \text { (Total loans } \\
\text { to private sector } \\
\text { from comm. banks)] }\end{array}$ & $\begin{array}{c}-0.594 \\
(\mathrm{pv}=0.068)\end{array}$ & - & $\begin{array}{c}-0.580 \\
(\mathrm{pv}=0.062)\end{array}$ \\
\hline $\begin{array}{l}\Delta[\text { Trade-weighted } \\
\text { Ex. rate volatility }]\end{array}$ & - & $\begin{array}{c}2.635 \\
(p v=0.200)\end{array}$ & $\begin{array}{c}0.524 \\
(\mathrm{pv}=0.606)\end{array}$ \\
\hline $\begin{array}{l}\Delta[\log (\mathrm{US} \$ \text { trade- } \\
\text { weighted exchange } \\
\text { rate)] }\end{array}$ & - & $\begin{array}{c}-0.852 \\
(\mathrm{pv}=0.033)\end{array}$ & $\begin{array}{c}-0.749 \\
(\mathrm{pv}=0.063)\end{array}$ \\
\hline $\begin{array}{l}\text { Negative rating: } \\
\text { S\&P and Moody's } \\
\text { (dummy variable) }\end{array}$ & $\begin{array}{c}0.037 \\
(\mathrm{pv}=0.008)\end{array}$ & $\begin{array}{c}0.032 \\
(\mathrm{pv}=0.011)\end{array}$ & $\begin{array}{c}0.037 \\
(\mathrm{pv}=0.004)\end{array}$ \\
\hline Cointegrating term & $\begin{array}{c}-0.080 \\
(\mathrm{pv}=0.000)\end{array}$ & $\begin{array}{c}-0.117 \\
(p v=0.000)\end{array}$ & $\begin{array}{c}-0.094 \\
(\mathrm{pv}=0.000)\end{array}$ \\
\hline Adj- $R^{2}$ & 0.126 & 0.141 & 0.177 \\
\hline AIC & -2.526 & -2.555 & -2.561 \\
\hline
\end{tabular}

The final results are presented in Table 3, which includes both the level relationship and the short-term error correction model (ECM). The interest rate variable was dropped because it was statistically and economically insignificant. The bounds cointegration test with F-Stat. = 4.88 test statistic exceeds the upper I (1) limit, thus indicating a level relationship at the five percent level. This is confirmed by the negative sign and high statistical significance of the cointegration term in the ECM. The LM serial correlation test for 12 lags indicates the absence of this problem. However, the ARCH (12) test indicates the presence of heteroscedasticity. 
Table 3 Long-run and short-run estimates: commercial banks' demand for NFAs

\begin{tabular}{|c|c|c|c|}
\hline \multirow{2}{*}{\multicolumn{2}{|c|}{$\begin{array}{l}\text { Long-run model } \\
\text { Dependent variable: log (commercial bank NFA) }\end{array}$}} & \multicolumn{2}{|c|}{ Short-run model } \\
\hline & & \multicolumn{2}{|c|}{$\begin{array}{l}\text { Dependent variable: } \Delta[\log \text { (commercial bank } \\
\text { NFA) }]\end{array}$} \\
\hline $\begin{array}{l}\text { Log (US\$ trade- weighted } \\
\text { exchange rate) }\end{array}$ & $\begin{array}{c}-1.331 \\
(\mathrm{pv}=0.016)\end{array}$ & $\begin{array}{l}\Delta[\log \quad(\mathrm{US} \$ \text { trade- } \\
\text { weighted exchange rate) }]\end{array}$ & $\begin{array}{c}-0.263 \\
(p v=0.450)\end{array}$ \\
\hline Log (Liquid bank reserves) & $\begin{array}{c}0.345 \\
(\mathrm{pv}=0.000)\end{array}$ & $\begin{array}{lll}\Delta[\log & \text { (Liquid } \quad \text { bank } \\
\text { reserves) }] & & \\
\end{array}$ & $\begin{array}{c}0.050 \\
(\mathrm{pv}=0.041)\end{array}$ \\
\hline Volatility: Oil price & $\begin{array}{c}0.308 \\
(\mathrm{pv}=0.081)\end{array}$ & $\Delta$ (Oil price volatility) & $\begin{array}{c}0.055 \\
(\mathrm{pv}=0.178)\end{array}$ \\
\hline Cointegration bounds test & $\begin{array}{l}\mathbf{4 . 8 8} *[5 \% \mathrm{I}(0) \\
\text { bound }=3.23 ; 5 \% \\
\mathrm{I}(1) \text { bound }=4.35]\end{array}$ & Cointegrating term & $\begin{array}{c}-0.122 \\
(\mathrm{pv}=0.000)\end{array}$ \\
\hline $\begin{array}{l}\text { Serial correlation: LM test: } \\
\text { F-Stat. }\end{array}$ & $\begin{array}{c}1.32 \\
(\mathrm{pv}=0.210)\end{array}$ & Adj-R ${ }^{2}$ & 0.084 \\
\hline ARCH (12): F-Stat. & $\begin{array}{c}2.17 \\
(\mathrm{pv}=0.015)^{* *}\end{array}$ & & \\
\hline
\end{tabular}

Nevertheless, the trade-weighted exchange rate has a statistically significant negative effect on NFAs, thus compounding the foreign exchange pressure on top of its much larger negative effect on CBB's reserves. The negative effect also holds in the short run, but it is statistically insignificant with a p-value of 0.45 . The coefficient estimate of LIQ has the expected sign and is statistically significant. This is consistent with the finding for Guyana by Khemraj (2009). It implies excess reserves from money printing do not make more loans, but they are used to purchase foreign currency assets. The oil price volatility has a larger effect in the long than short term.

\section{CONCLUSION}

This papwer explains why Barbados finds itself in a situation of acute FX shortages approximately every ten to twelve years. External factors are the main drivers, not a profligate government. The proposed monetary dependency model explains that the build-up of liquid assets is a signal that the government and central bank are leaning against global headwinds while trying to maintain social goals at home. The monetary strategy involves offsetting the demand for foreign-currency assets with local treasury bills. This strategy is often seen as mopping up excess reserves. However, it is part of a compensation strategy that involves 
displacing the private sector's demand for foreign securities with domestic ones. This strategy is at the center of monetary policy that does not require an interest rate instrument - as there is no well-developed interbank market and the loan rate is a markup - but quantitative adjustments of a national security via one-sided sales.

Although we found weak evidence in favor of CBB's money printing contributing to the decline in international reserves, the results are much stronger in favor of the monetary dependency thesis. Furthermore, the model of monetary dependency proposed herein is applicable beyond Barbados. The latter thesis implies that external economic forces are responsible for the foreign exchange pressure in an economy in the periphery. In particular, the strongest determinant is the U.S. trade-weighted exchange rate. This means that in spite of its fixed exchange rate, Barbados' foreign exchange availability both at central bank and commercial banks is determined by the dollar's trade-weighted rate. In other words, the de facto exchange rate of this fixed exchange rate economy is the American trade-weighted rate relative to the trading partners of United States. As the rate appreciates, it makes it expensive for nonAmerican tourists to visit Barbados and increases the amount of U.S. dollars Barbados would need to import capital goods.

These findings raise serious doubts whether the policy response of austerity can address the conditions necessary to create resilience to global shocks. The austerity measures have to be supported by efforts to reorganize the economic structure of production to conserve and generate foreign currencies. The authorities can also explore alternative auctioning mechanisms for government treasury bills, since these quantity adjustments represent the best way forward for short-run stabilization while at the same time meeting social obligations. Price signaling via interest rate instrument is unlikely to work in a system of oligopolistic banking. The return of a few indigenous banks might also help.

\section{REFERENCES}

Aizenman, J. and M. Hutchison (2012) 'Exchange market pressure and absorption by international reserves: Emerging markets and fear of reserve loss during the 2008 - 2009 crisis," Journal of International Money and Finance, 31 (Issue 5), 1076 - 1091.

Bakker, B. B. (1993) 'Net foreign assets of Dutch commercial banks, 1984 - 1990, De Economist, 41(93), $432-441$. 
Bell, S. (2000), 'Do taxes and bonds finance government spending?' Journal of Economic Issues, 34 (3), $603-620$.

Coelho, G. G. and E. Perez-Caldentey (2018) 'Neo-Kaleckian models with financial cycles: a centre-periphery framework,' PSL Quarterly Review, 71 (286), September.

Dixon-Fyle, S. R. (1978) 'Monetary dependence in Africa: the case of Sierra Leone,' Journal of Modern African Studies, 16 (2), 273 - 294.

Erten, B. (2011) 'North-South terms-of-trade trends from 1960 to 2006,' International Review of Applied Economics, 25 (2), $171-184$.

Erten, B. and J. A. Ocampo (2013) 'Super cycles of commodity prices since the mid-Nineteenth Century,' World Development, 44 (April), 14 - 30.

Gevorkyan, A. V. (2017) 'The foreign exchange regime in a small open economy: Armenia and beyond,' Journal of Economic Studies, 44 (5), 781 - 800.

IMF (2018), Barbados: Article IV Consultation - Press Release; Staff Report; and Statement by the Executive Director for Barbados, IMF Country Report No. 18/133, Washington, DC: International Monetary Fund.

Jha, R. (1994) Macroeconomics for Developing Countries, London and New York: Routledge.

Khemraj, T. (2018), 'Monetary policy and excess liquid assets in small open developing economies,' in L. Briguglio (ed.) Handbook of Small States: Economic, Social and Environmental Issues, London and New York: Routledge Taylor and Francis.

Khemraj, T. (2014) Money, Banking and the Foreign Exchange Market in Emerging Economies, Cheltenham, UK and Northampton, MA, USA: Edward Elgar.

Khemraj, T. (2009) 'Excess liquidity and the foreign currency constraint: the case of monetary management in Guyana,' Applied Economics, 41 (16), 2073 - 2084.

Lavoie, M. (2006) Introduction to Post-Keynesian Economics, New York: Palgrave Macmillan.

Lavoie, M. (2001), 'The reflux mechanism and the open economy', in L.-P Rochan and M. Vernengo (eds.), Credit, Interest Rates and the Open Economy, Cheltenham, UK and Northampton, MA: Edward Elgar.

Lavoie, M. and P. Wang (2012) 'The 'compensation' thesis, as exemplified by the case of the Chinese central bank,' International Review of Applied Economics, 26 (3), 287 - 301.

McClean, W. A. (1998) 'The M1-M10 relation in Barbados: some evidence on causality,' Paper presented at the Annual Review Seminar, Research Department, Central Bank of Barbados, July 28-31. 
McClean, W. A. (1985) 'A further comment on the conventional money multiplier,' Social and Economic Studies, 34 (3), 259 - 264.

McKinnon, R. I. (2000) 'On the periphery of the dollar standard: Canada, Latin America, and East Asia,' North American Journal of Economics and Finance, 11 (2), 105 - 121.

Moosa, I. A. (2017) 'Blaming suicide on NASA and divorce on margarine: the hazard of using cointegration to derive inference on spurious correlation,' Applied Economics, 49 (15), 1483 1490.

Pesaran, H., Y. Shin and R. Smith (2001) 'Bounds testing approaches to the analysis of level relationships,' Journal of Applied Econometrics, 16 (June), 289 - 326.

Thomas, C. Y. (1965) 'Monetary and financial arrangements in a dependent monetary economy: a study of British Guiana, 1945 - 1962,' Social and Economic Studies, Supplement to Vol. 14 (4), $1-186$.

Worrell, D. (1997) 'The role models for monetary policy in the Caribbean: comparing CARICOM central banks,' in H. Codrington, R. Craigwell and C. Haynes (eds.) Central Banking in Barbados: Reflections and Challenges, Bridgetown: Central Bank of Barbados.

Worrell, D. (1995) 'Open market operations in small open economies with fixed and flexible exchange rates,' Social and Economic Studies, 44 (4), 139 - 153.

Vernengo, M. and L.-P. Rochon (2001) 'Kaldor and Robinson on money and growth,' European Journal of History of Economic Thought, 8 (1), 75 - 103.

Ziesemer, T. H. W. (2014) 'Country terms of trade: trends, unit roots, over-differencing, endogeneity, time dummies, and heterogeneity,' International Review of Applied Economics, 28 (6), 767 - 796. 